\title{
Identification of Resistance to Powdery Mildew in Chile Pepper
}

\author{
Jack E. McCoy and Paul W. Bosland ${ }^{1}$ \\ Department of Plant and Environmental Sciences, New Mexico State \\ University, Las Cruces, NM 88003 \\ Additional index words. Capsicum, disease resistance, Leveillula taurica, powdery mildew
}

\begin{abstract}
Powdery mildew [Leveillula taurica (Lév.) Arn] is a fungus causing epidemics on chile peppers (Capsicum sp.) worldwide. It was first observed in New Mexico in the late 1990s and has been a reoccurring issue. During the 2017 growing season, environmental conditions were highly favorable for powdery mildew development and severe infection was observed. This provided a unique opportunity to identify novel sources of resistance in Capsicum to powdery mildew. In the present study, the incidence and severity of powdery mildew was evaluated for 152 chile pepper accessions comprising different cultivars and species. Major differences in disease severity and incidence were observed among the accessions. Of the 152 accessions, 53 were resistant, i.e., received a disease index (DI) score of $\leq 1$. When examining across Capsicum species, 16 Capsicum annuum accessions, all 8 Capsicum baccatum, all 21 Capsicum chinense, 5 of 6 Capsicum frutescens, the Capsicum chacoense accession, and the Capsicum rhomboideum accession were resistant. These results provide several accessions with resistance that can be used in breeding programs. Especially important are the $C$. annuum resistant accessions, as this resistance can be more quickly incorporated into commercially important $C$. annuum cultivars as compared with interspecific hybridizations.
\end{abstract}

Chile peppers (Capsicum sp.) are a widely cultivated crop that is a staple in the diet of many cultures worldwide and is used as a vegetable, spice, ornamental, and medicinal plant (Bosland and Votava, 2012). There are five domesticated species: C. annuum L., C. baccatum L., C. chinense Jacq., C. frutescens L., and C. pubescens Ruiz and Pav., with $C$. annuum providing most of the commercial production in the world. In New Mexico, the chile pepper industry has cultural and economic significance with New Mexico having the largest area of chile pepper production in the United States (USDA, 2017).

A relatively new disease affecting chile pepper production in New Mexico is powdery mildew incited by L. taurica (Lév.) Arn. Powdery mildew is a major foliar disease that can cause serious economic losses (Palti, 1988). It is widely distributed in chile pepper production areas with confirmed existence from dry regions of Asia and the Mediterranean to more humid regions (Palti, 1988). It was reported in the North-Central Mexico states of Chihuahua, Zacatecas, and Aguascalientes in 1999 (Velásquez-Valle and ValleGarcia, 1999). Since its introduction into the southwest region of the United States, losses to powdery mildew have varied year to year, with severe infection early in the season causing heavy yield losses (Murray, 2000). Application of fungicides may manage the

Received for publication 26 Sept. 2018. Accepted for publication 23 Oct. 2018.

This work was supported by the New Mexico Agr. Exp. Station/New Mexico Chile Improvement Program.

${ }^{1}$ Corresponding author. E-mail: pbosland@nmsu. edu.

is through resistant cultivars. In this study, a wide range of germplasm was evaluated for resistance to powdery mildew.

\section{Materials and Methods}

Plant material. The Chile Pepper Institute (CPI) plants a teaching garden annually at the Fabian Garcia Science Center in Las Cruces, $\mathrm{NM}$ (lat. $32.3199^{\circ} \mathrm{N}$, long. $106.7637^{\circ} \mathrm{W}$ ). During the 2017 growing season, environmental conditions were highly favorable for powdery mildew development and severe infection occurred throughout the garden. In fact, the disease level was the highest seen in more than a decade. The garden has been used in the past to identify serendipitous sources of salt tolerance (Votava and Bosland, 2002) and curly top virus resistance (Bosland, 2000) within Capsicum. With more than 152 accessions growing in the garden, it provided a unique and exceptional opportunity to evaluate for novel sources of powdery mildew resistance (Table 1). This included six Capsicum species: C. annuum, C. baccatum, $C$. chinense, $C$. frutescens, $C$. chacoense Hunz., and C. rhomboideum (Dunal) Kuntze.

Plant culture. The CPI Teaching Garden is managed according to standard New Mexico cultivation practices (Bosland and Walker, 2014). Seeds were sown into a planting medium (Sunshine Redi-Earth Plug $\&$ Seedling Mix; Sun Gro Horticulture, Bellevue, WA) in 12-celled bedding plant containers (Hummert Intl., Earth City, MO) and placed in a greenhouse maintained at $27{ }^{\circ} \mathrm{C}$ day $/ 18^{\circ} \mathrm{C}$ night $\pm 3{ }^{\circ} \mathrm{C}$. Plants were transplanted from the greenhouse to the CPI Teaching Garden location, a Glendale loam soil. The plants were spaced $30 \mathrm{~cm}$ apart within row in 1-m-wide rows, and furrow irrigated and fertilized as needed.

Disease scoring. Plants were grown under natural infection conditions and were evaluated once when disease had reached its highest level throughout the field. Plants were scored based on a modified DI developed by Zheng et al. (2013). The DI is a scale of 0 to 5 , where $0=$ no visible sporulation, $1=$ restricted chlorotic spots on the adaxial leaf surface, with weak or no sporulation on the abaxial leaf area; 2 = several isolated sporulation spots on the abaxial leaf area; $3=$ numerous sporulation spots covering up to $40 \%$ to $50 \%$ of the abaxial leaf area; $4=$ numerous coalescent sporulation spots covering up to $75 \%$ of the abaxial leaf area; and $5=$ the whole abaxial surface of the leaf, and also parts of the adaxial leaf surface, covered with dense sporulation (Zheng et al., 2013; Fig. 1). Plants were considered to be resistant if DI $\leq 1$. Moderately resistant accessions are also noted and are defined as plants with an average score of less than 2 and with no more than five individual leaves with a score of 2 or less. Within each accession, five random plants were chosen and three individual leaves per plant were assigned a DI rating. Disease scores were analyzed using $\mathrm{R}$ version 3.4.2 (2017).

\section{Results}

Of the 152 accessions, evaluated for their reaction to natural field incidence and severity of powdery mildew in the CPI Teaching Garden, 53 were resistant, i.e., a DI score of $\leq 1$ (Table 2). When examining across Capsicum species, 16 of 115 C. annuum accessions were resistant, as well as the 8 of $8 C$. baccatum accessions, 21 of $21 C$. chinense accessions, 5 of 6 C. frutescens accessions, the $C$. chacoense accession and the $C$. rhomboideum accession. In addition, seven accessions were moderately resistant, with low levels of sporulation and few chlorotic lesions (Table 3 ).

A hypersensitive response (HR) and early leaf senescence were observed in some accessions, where small chlorotic lesions were noted. This indicated that powdery mildew infection had clearly occurred but did not spread and had no visible sporulation (Fig. 2). In C. frutescens 'Siling Labuyo' and in $C$. baccatum 'Suriname Color' an HR was observed, and both had a DI rating of 0.73 . Early leaf senescence was observed for $C$. rhomboideum and C. chinense 'NuMex Farolito', where leaves appeared to shed early in infection, preventing the spread of the disease on the plant.

\section{Discussion}

Results of this investigation suggest significant sources of resistance for powdery mildew exist within Capsicum species. This 
Table 1. List of Capsicum accessions evaluated for powdery mildew (Leveillula taurica) resistance in the 2017 Chile Pepper Institute Teaching Garden.

\begin{tabular}{|c|c|}
\hline Species & Accession $^{2}$ \\
\hline $\begin{array}{l}\text { C. annuum var. } \\
\text { glabriusculum }\end{array}$ & Chiltepín \\
\hline C. frutescens & Birds Eye, Diente de Perro, Puta Pario, Siling Labuyo, Tabasco, and Zimbabwe Bird \\
\hline C. rhomboideum & NMCA 50064 \\
\hline
\end{tabular}

${ }^{\mathrm{z}}$ Accessions listed in alphabetical order by species.

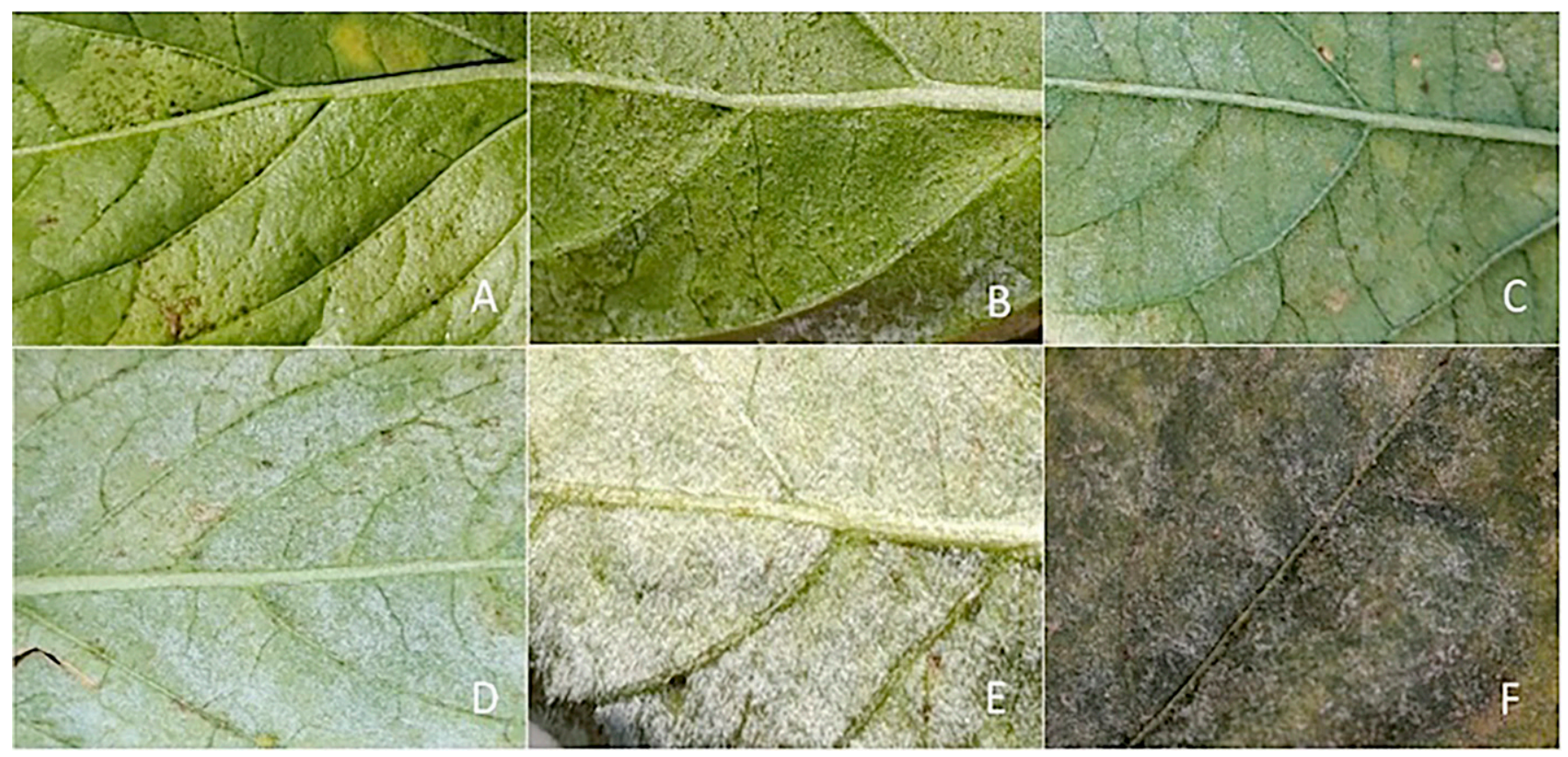

Fig. 1. Disease index (DI) for powdery mildew based on Zheng et al. (2013). (A) DI =1, (B) DI =2, (C) DI $=3$, (D) DI $=4,(\mathbf{E}) \mathrm{DI}=5$, abaxial, and (F) DI $=5$, adaxial, where $0=$ no visible sporulation, $1=$ restricted chlorotic spots on the adaxial leaf surface, with weak or no sporulation on the abaxial leaf area; $2=$ several isolated sporulation spots on the abaxial leaf area; 3 = numerous sporulation spots covering up to $40 \%$ to $50 \%$ of the abaxial leaf area; $4=$ numerous coalescent sporulation spots covering up to $75 \%$ of the abaxial leaf area; and $5=$ the whole abaxial surface of the leaf, and also parts of the adaxial leaf surface, covered with dense sporulation.

is the first evaluation of plant materials in New Mexico for powdery mildew resistance. In Brazil, Souza and Café-Filho (2003) evaluated 162 Capsicum accessions and found that most $C$. annuum material was susceptible; however, $C$. baccatum, C. chinense, and C. frutescens are mostly resistant. The findings of this study support the observations of Souza and Café-Filho (2003) that C. baccatum, $C$. chinense, and $C$. frutescens are mostly resistant. However, this study identified new sources of resistance within the germplasm evaluated.

Preliminary work on the mildew resistance locus $O$ (Mlo) in these chile pepper accessions was carried out. The CaMlo2 allele, identified by Kim and Hwang (2012), was sequenced and early screening suggests it could play a role in resistance for some of the accessions in this study (data not shown).
Early reports of $m l o$-mediated resistance in barley indicate a phenotype with a tendency toward pronounced necrotic or chlorotic leaf spotting and occasional mildew colonies (Jørgensen, 1992). Necrotic and chlorotic leaf spotting reported by Jørgensen (1992) is similar to the HR characteristics observed in this study. In an investigation into accumulation of $\mathrm{H}_{2} \mathrm{O}_{2}$ because of loss-of-function of mlo gene, Piffanelli et al. (2002) reported a 
Table 2. Resistant accessions from the 2017 Chile Pepper Institute Teaching Garden in Las Cruces, NM.

\begin{tabular}{|c|c|c|}
\hline Species & Accession $^{2}$ & Mean Score ${ }^{y}$ \\
\hline \multirow[t]{11}{*}{ Capsicum annuum } & NuMex Veteran's Day & $0.20 \pm 0.41$ \\
\hline & Purple Flash & $0.33 \pm 0.49$ \\
\hline & NuMex St. Patrick's Day & $0.53 \pm 0.52$ \\
\hline & NuMex Halloween & $0.60 \pm 0.51$ \\
\hline & NuMex Thanksgiving & $0.60 \pm 0.51$ \\
\hline & NuMex Chinese New Year & $0.67 \pm 0.49$ \\
\hline & Guatemalan & $0.87 \pm 0.35$ \\
\hline & NuMex April Fool's Day & $0.87 \pm 0.35$ \\
\hline & NuMex Las Cruces Cayenne & $0.93 \pm 0.26$ \\
\hline & NuMex Summer Solstice & $0.93 \pm 0.26$ \\
\hline & Corcel & $1.00 \pm 0.00$ \\
\hline C. аппиит var. glabriusculum & Chiltepín & $0.47 \pm 0.52$ \\
\hline \multirow{6}{*}{ C. baccatum } & Omnicolor & $0.47 \pm 0.52$ \\
\hline & Petch Mordindang & $0.47 \pm 0.52$ \\
\hline & Aji Limon & $0.53 \pm 0.52$ \\
\hline & Peri Peri & $0.53 \pm 0.52$ \\
\hline & Rocotillo & $0.67 \pm 0.49$ \\
\hline & Suriname Color & $0.73 \pm 0.46$ \\
\hline \multirow[t]{8}{*}{ C. chinense } & NuMex Trick-or-Treat & $0.13 \pm 0.35$ \\
\hline & Brown Habanero & $0.20 \pm 0.41$ \\
\hline & Maya & $0.27 \pm 0.46$ \\
\hline & NuMex Farolito & $0.27 \pm 0.46$ \\
\hline & Red Caribbean Habanero & $0.27 \pm 0.46$ \\
\hline & Habanada & $0.33 \pm 0.49$ \\
\hline & NuMex Suave Red & $0.33 \pm 0.49$ \\
\hline & Aji Rojo & $0.93 \pm 0.23$ \\
\hline C. chacoense & NMCA 50009 & $0.47 \pm 0.52$ \\
\hline \multirow[t]{5}{*}{ C. frutescens } & Puta Pario & $0.07 \pm 0.26$ \\
\hline & Zimbabwe Bird & $0.13 \pm 0.35$ \\
\hline & Diente de Perro & $0.20 \pm 0.41$ \\
\hline & Tabasco & $0.53 \pm 0.52$ \\
\hline & Birds Eye & $0.67 \pm 0.49$ \\
\hline C. rhomboideum & 50,064 & $0.20 \pm 0.41$ \\
\hline
\end{tabular}

${ }^{\mathrm{z}}$ Accessions listed by species from lowest to highest disease rating.

${ }^{\mathrm{y}}$ Mean disease index score with corresponding SD.

Table 3. Moderately resistant ${ }^{2}$ accessions from the 2017 Chile Pepper Institute Teaching Garden in Las Cruces, NM.

\begin{tabular}{llr}
\hline Species & \multicolumn{1}{c}{ Accession $^{\mathrm{y}}$} & Mean score $^{\mathrm{x}}$ \\
\hline Capsicum annuum & Calico & $0.47 \pm 0.74$ \\
& NuMex Twilight & $0.93 \pm 0.46$ \\
& Brebes & $0.93 \pm 0.59$ \\
& NuMex Valentine's Day & $1.07 \pm 0.26$ \\
& Mulato & $1.07 \pm 0.46$ \\
C. frutescens & Shishito & $1.20 \pm 0.56$ \\
\hline
\end{tabular}

${ }^{\mathrm{z}}$ Moderately resistance is defined as plants with and average score of less than 2 , and no more than five individual leaves with a score of 2.

${ }^{\mathrm{y}}$ Accessions listed by species from lowest to highest disease rating.

${ }^{\mathrm{x}}$ Mean disease index score with corresponding SD.

premature cell-death phenotype that mimics leaf senescence. The HR and early leaf senescence phenotype observed in some of the populations suggest that recessive
Camlo2-mediated resistance may explain resistance within some accessions in this study.

CaMlo2 could explain the variability within the population, but there may be other genetic mechanisms controlling powdery mildew resistance. Recently, a novel gene, $P M R 1$, was identified as conferring resistance in C. annuum (Jo et al., 2017). The 


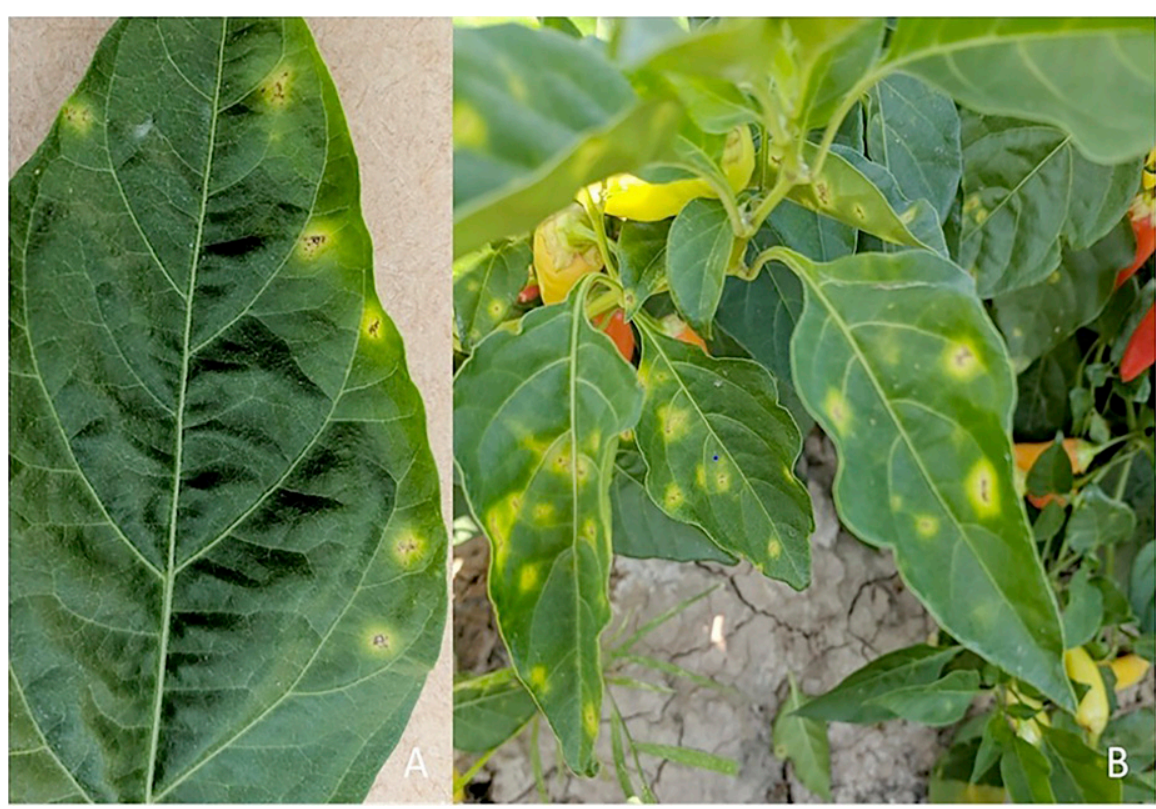

Fig. 2. Hypersensitive response (HR) to plant infection by powdery mildew on individual leaf (A) and entire plant (B). HR was given a disease index score of 1 .

single dominant gene, $P M R 1$, was identified through two mapping populations (Jo et al., 2017). It would be worthwhile to screen the evaluated material in this study with the PMR1 marker.

Several accessions were identified in this study to have significant levels of resistance that can be used in a Capsicum breeding program. Especially important are the $C$. annuum resistant accessions, as their resistance can be more quickly incorporated into commercial cultivars, which are mainly $C$. annuum. A follow-up experiment using artificial inoculation of resistant germplasm identified in this study, as well as additional

results. This is the first study evaluating resistance in germplasm exposed to the New Mexico powdery mildew pathotype and provides a basis for continued breeding efforts toward powdery mildew resistance in New Mexico, and globally.

\section{Literature Cited}

Bosland, P.W. 2000. Sources of curly top virus resistance in Capsicum. HortScience 35:13211322.

Bosland, P.W. and E.J. Votava. 2012. Peppers vegetable and spice capsicums. 2nd ed. CABI, Cambridge, MA.
Bosland, P.W. and S. Walker. 2014. Growing chiles in New Mexico. NMSU Coop. Ext. Serv. Guide $\mathrm{H}-230$.

Goldberg, N. 2004. Powdery mildew on chile peppers. NMSU Coop. Ext. Serv. Guide H-248.

Jo, J., J. Venkatesh, K. Han, H.Y. Lee, G.J. Choi, H.J. Lee, D. Choi, and B.C. Kang. 2017. Molecular mapping of PMR1, a novel locus conferring resistance to powdery mildew in pepper (Capsicum annuum). Front. Plant Sci. 8:1-11.

Jørgensen, J.H. 1992. Discovery, characterization and exploitation of Mlo powdery mildew resistance in barley. Euphytica 63:141-152.

Kim, D.S. and B.K. Hwang. 2012. The pepper $M L O$ gene, $C a M L O 2$, is involved in the susceptibility cell-death response and bacterial and oomycete proliferation. Plant J. 72:843855.

Murray, M.W. 2000. Crop profile for peppers (chile) in New Mexico. New Mexico Coop. Ext. Serv. Plant Sci. Dept.

Palti, J. 1988. The Leveillula mildews. Bot. Rev. 54:423-535.

Piffanelli, P., F. Zhou, C. Casais, J. Orme, B. Jarosch, U. Schaffrath, N.C. Collins, R. Panstruga, and P. Schulze-Lefert. 2002. The barley $M L O$ modulator of defense and cell death is responsive to biotic and abiotic stress stimuli. Plant Physiol. 129:1076-1085.

Souza, V.L. and A.C. Café-Filho. 2003. Resistance to Leveillula taurica in the genus Capsicum. Plant Pathol. 52:613-619.
U.S. Department of Agriculture. 2017. Vegetables 2016 summary. U.S. Dept. Agr., Washington, DC.

Velásquez-Valle, R. and P. Valle-Garcia. 1999. First report of powdery mildew of pepper in north-central Mexico. Plant Dis. 84:302.

Votava, E.J. and P.W. Bosland. 2002. Sources of salt tolerance in Capsicum. Capsicum Eggplant Nwsl. 21:64-65.

Zheng, Z., T. Nonomura, K. Bóka, Y. Matsuda, R.G.F. Visser, H. Toyoda, L. Kiss, and Y. Bai. 2013. Detection and quantification of Leveillula taurica growth in pepper leaves. Phytopathology 103:623-632. 